American Journal of Agricultural and Biological Sciences 4 (2): 131-136, 2009

ISSN 1557-4989

(C) 2009 Science Publications

\title{
Effects of Tillage Methods on Soil Fragmentation in Loamy-Clay Soils
}

\author{
${ }^{1}$ Yousef Abbaspour-Gilandeh, ${ }^{1}$ Vali Rasooli Sharabiani and ${ }^{2}$ Ahmad Khalilian \\ ${ }^{1}$ Department of Agricultural Machinery, \\ College of Agriculture, University of Mohaghegh Ardabili, Ardabil, Iran \\ ${ }^{2}$ Department of Agriculture and Biosystem Engineering, Clemson University, \\ Edisto Research and Education Center, 64 Research Road, Blackville, SC 29817, USA
}

\begin{abstract}
Problem statement: Soil fragmentation is a primary aim in tillage in order to create a favorable soil environment for crop growth. Soil fragmentation is defined as the process of breakdown and crumbling of soil aggregates. Currently, there is no published research data on optimum tillage operations for seedbed preparation in loamy-clay soils of western Caspian Sea region of Iran. Approach: Tests were conducted on a loamy-clay soil near the city of Ardabil, Iran, to investigate the effects of different tillage operations on soil crumbling. Four tillage treatments: Moldboard plow (M) (conventional method), Moldboard plow and Disk-Harrow (MH), Decompactor and Moldboard plow (DM) and De-Compactor and Disk-Harrow (DH) were used in this study with four replications. The tillage depth for all treatments was about $30 \mathrm{~cm}$. Following tillage operations, intensive soil samples were taken from the top $25 \mathrm{~cm}$ of soil at $5 \mathrm{~cm}$ depth increments and were analyzed for aggregate size and distribution using 9 standard sieves $(0.25-19 \mathrm{~mm}$ mesh). Analysis of variance was carried out regarding soil crumbling percentage and mean diameter of soil aggregates in each treatment. The experiment was arranged in a split-plot design with five levels of soil sampling depths and two main factors (tillage method and tillage depth) which were arranged in Latin Square design. Results: Results showed that the tillage treatments had a significant effect on soil crumbling. Also, soil crumbling varied with soil depth and the optimum particle sizes were developed at the $5-20 \mathrm{~cm}$ soil depth. There was a non-linear correlation between soil crumbling percentage and tillage depth. Conclusion/Recommendations: Tillage methods and soil sampling depth had interaction effect on soil crumbling percentage. The MH treatment had the greatest amount of soil crumbling and the best seed-bed condition.
\end{abstract}

Key words: Tillage equipment combinations, soil crumbling, aggregate size, soil moisture content

\section{INTRODUCTION}

Soil is a heterogeneous medium; composed of primary particles, aggregates, pores and organic matter ${ }^{[7]}$. Ladd et al. defined soil structure simply as "the size, shape and arrangement of particles in soil" ${ }^{[12]}$. Soil fragmentation is a primary aim in tillage in order to create a favorable soil environment for crop growth. Soil fragmentation is defined as the process of breakdown and crumbling of soil aggregates. Soil fragmentation occurs naturally as a result of wetting/drying and freezing/thawing cycles. However, the major cause of fragmentation in most agricultural soils is because of primary and secondary tillage ${ }^{[15]}$.

Soil fragmentation may be determined by measurements such as the increase in surface area or decrease in Mean Weight Diameter (MWD). Gill and
Vanden Berg $^{[9]}$ described a rotary sieve designed for this purpose. The results may be expressed in terms of the actual size distribution of the clods, a mean-mass diameter, or a pulverization modulus ${ }^{[8,9]}$.

Crops require ample aeration for the plant roots and for decomposition of organic matter and at the same time an adequate soil/root contact to secure uptake of water and nutrients ${ }^{[7]}$. Karlen et al. ${ }^{[10]}$ stated that a soil with a good soil tilth "usually is loose, friable and well granulated". Braunack and Dexter ${ }^{[5]}$ reported that the optimal seedbed (i.e., the soil layer that has been tilled to a condition to promote seed germination and the emergence of seedlings) is produced by $0.5-8 \mathrm{~mm}$ aggregates. Berntsen and Berre ${ }^{[3]}$ reported that an optimal seedbed for cereals is characterized by about $50 \%$ of the aggregates by mass in the $0.5-6 \mathrm{~mm}$ fraction and an even and firm layer below the seedbed

Corresponding Author: Yousef Abbaspour-Gilandeh, Department of Agricultural Machinery, College of Agriculture, University of Mohaghegh Ardabili, Ardabil, Iran 
prepared top-layer. A large fraction of small aggregates $(<0.5-1 \mathrm{~mm})$ is not desirable because of increased risk of wind and water erosion. Furthermore a large fraction of aggregates larger than $8 \mathrm{~mm}$ is not desirable because of a reduction in the soil/root contact area and a higher impedance to root penetration. Misra et al. ${ }^{[13]}$ showed that axial root penetration forces for cotton, sunflower and pea increased with increasing aggregate size up to about $12 \mathrm{~mm}$ in aggregate diameter.

Soil management affects soil fragmentation through effects on soil structure formation due to the influence of soil tillage methods. In general, factors that enhance clay dispersion have been found to result in increased tensile strength of dry aggregates and therefore reduced ease of preparing a desirable arable layer ${ }^{[2,11,16]}$. Soil compaction may not only induce clay dispersion, but also increase the number of contact points between the soil elements.

Berntsen and Berre ${ }^{[4]}$ conducted field experiments over a period of 6 years to study the effects of secondary tillage implements on soil fragmentation. Seedbed preparation was carried out on four different sites with clay contents of 45, 27, 24 and 15\%. Three implement groups (drags and harrows; twin rotor; gyroand rota spikes) were used for seedbed preparation in the spring. The results showed no difference in fragmentation between harrows and rotary fragmentation implements. For the loosened soil state, there was no significant difference between the three implement groups. Rotary implements seemed, however, to be more effective in the conversion of energy to fragmentation.

Traditionally farmers in the western Caspian Sea region of Iran, use moldboard plow for crop productions. Currently, there is no published research data on optimum tillage operations for seedbed preparation in loamy-clay soils of this region. Therefore, the objective of this study was to investigate the effect of tillage implement and tillage depth on soil fragmentation in loamy-clay soils

\section{MATERIALS AND METHODS}

Field experiments: Tests were conducted on a loamyclay soil near the city of Ardabil, Iran (Latitude $38^{\circ} 10^{\prime} \mathrm{N}$, Longitude $48^{\circ} 23^{\prime} \mathrm{E}$ ), to investigate the effects of different tillage operations on soil aggregate size distribution and soil crumbling. Four tillage implement combinations were used in this study: (1) Moldboard plow (M) (conventional method), (2) Moldboard plow and disk-harrow (MH), (3) De-compactor and moldboard plow (DM) and (4) de-compactor and DiskHarrow (DH). The tillage depth for all treatments was about $30 \mathrm{~cm}$. Experiments were arranged in a split-plot design with five levels (five soil sampling depths) and two main factors (tillage systems and tillage depth) which were arranged in a Latin Square design with four rows and four columns. In this design every treatment occurs only once in each row and each column. The test field was divided into 16 plots $(6 \times 22 \mathrm{~m})$ and treatments were replicated four times. Means of treatments values, soil sampling depth and reciprocal effect between them were tested using Duncan test.

Measurements and analyses: Prior to tillage operations, soil samples were taken from each plot at the depth of $0-30 \mathrm{~cm}$, to document the field variation in terms of soil texture, using the standard cylinder method $^{[6]}$. Following tillage operations, intensive soil samples were taken from the top $25 \mathrm{~cm}$ of soil at $5 \mathrm{~cm}$ depth increments. The samples were sieved into 9 diameter classes from 0.25-19 $\mathrm{mm}$ using standard sieves. The cumulative amount of soil retained on each sieve was weighed. The degree of fragmentation (crumbling) in different tillage treatments and sampling depths were expressed by the change of the Mean Weight Diameter (MWD). The MWD is calculated by the expression:

$M W D=\frac{\sum_{i=1}^{n} w_{i} \bar{d}_{i}}{G}$

Where:

$\mathrm{w}_{\mathrm{i}}=$ The mass of aggregates obtained between two sieve openings $d_{i}$ and $d_{i+1}$

$\mathrm{G}=$ The weight of the total mass

$\mathrm{n}=$ The number of sieves

In Eq. 1, $\overline{\mathrm{d}}_{\mathrm{i}}$ was calculated using the following equation:

$\overline{\mathrm{d}}_{\mathrm{i}}=\frac{1}{2}\left(\mathrm{~d}_{\mathrm{i}}+\mathrm{d}_{\mathrm{i}+1}\right)$

Soil moisture samples were collected at three depth ranges of $0-10,10-20$ and $20-30 \mathrm{~cm}$ using a hand-held soil probe. The soil cans and soil samples were weighted and dried at $105^{\circ} \mathrm{C}$ for $24 \mathrm{~h}$. The moisture content $(\mathrm{MC} \%)$ of each sample was calculated on a percent dry weight basis by the following formula:

$\mathrm{MC}(\%)=\frac{\mathrm{W}_{\mathrm{wet}}-\mathrm{W}_{\mathrm{dry}}}{\mathrm{W}_{\mathrm{dry}}} \times 100$

Where:

$\mathrm{W}_{\text {wet }}=$ The weight of the wet soil sample $(\mathrm{g})$

$\mathrm{W}_{\mathrm{dry}}=$ The weight of the dried soil sample $(\mathrm{g})$ 
Soil samples from different locations of the test area were also obtained to study the physical and chemical properties of the soil layers that affect the formation of the hardpan layer.

Soil bulk density was calculated by using the following formula:

$$
\mathrm{BD}=\frac{\mathrm{W}_{\mathrm{dry}}}{\mathrm{V}}
$$

Where:

$\mathrm{BD}=$ The dry bulk density $\left(\mathrm{g} \mathrm{cm}^{-3}\right)$

$\mathrm{W}_{\text {dry }}=$ The weight of the dried soil sample $(\mathrm{g})$

$\mathrm{V}=$ The total volume of the soil sample $\left(\mathrm{cm}^{3}\right)$

The volumetric water content, in the soil represents the fraction of the total volume of soil that is occupied by the water contained in the soil. Assuming that $V_{1}$ is the volume of the liquid phase (water) in the soil sample and that $\mathrm{V}_{\mathrm{t}}$ is the total volume of the sample, the volumetric water content can then be defined as follows:

$$
\mathrm{VWC}=\frac{\mathrm{V}_{1}}{\mathrm{~V}_{\mathrm{t}}}=\frac{\mathrm{V}_{1}}{\mathrm{~V}_{\mathrm{s}}+\mathrm{V}_{\mathrm{p}}}
$$

where, $\mathrm{V}_{\mathrm{s}}$ and $\mathrm{V}_{\mathrm{p}}$ represent, respectively, the volumes of the solid phase and the pore space.

The treatments effects were evaluated by Duncan test based on Latin Square Design with split plots (five sampling depth) and two main factors (tillage method and plowing depths).

\section{RESULTS}

The results of field measurements indicated that the mean gravimetric water content, the mean volumetric water content and the mean dry bulk density were 7.67 , 10.36 and $1.35 \%$ respectively. Regarding the loamyclay texture of the soil, these results implied the relatively heaviness of the soil (44\% clay). In addition, the mean dry bulk density of $1.35 \mathrm{~g} \mathrm{~cm}^{-3}$ implied the presence of some sand in the soil ( $12 \%$ clay).
The Results showed that for the experiment with five levels of soil sampling depths and two main factors of tillage combination and tillage depth arranged in Latin Square design, column and replication effect were not significant for soil aggregate size larger than $19 \mathrm{~mm}$. The amount of soil crumbling was significantly different between tillage treatments $(p<0.01)$; however, sampling depth had a significant effect on soil aggregate diameter $(\mathrm{p}<0.01)$. For the soil crumbling with aggregate sizes greater $19 \mathrm{~mm}$, the interaction between tillage treatment and sampling depth was not significant.

Also, for the soil particle size between 11.2-19 mm, the column and replication effect were not significant. Tillage implements had a significant effect on soil crumbling $(\mathrm{p}<0.01)$; however, tillage depth had no significant effect on soil particle diameter at this rage $(\mathrm{p}<0.01)$. The interaction between tillage and sampling depth effects on soil crumbling was not significant $(p<0.01)$. This means that for soil aggregates in the range of 11.2-19 $\mathrm{mm}$ not only tillage methods but also tillage depth have affected soil crumbling.

For the soil aggregates in the size range of 4.75$11.2 \mathrm{~mm}$, tillage treatments affected soil crumbling significantly $(\mathrm{p}<0.01)$ and also tillage depth had a significant effect on soil particle size.

Results showed that for the treatments arranged in a Latin Square design, column and replication effect were not significant for aggregate size between $2.8-4.75 \mathrm{~mm}$ but soil crumbling was affected by replication effect $(\mathrm{p}<0.01)$. Also soil crumbling was significant between tillage implement combinations $(\mathrm{p}<0.01)$ and also tillage depth had a significant effect on soil particle diameter $(\mathrm{p}<0.05)$. However, the interaction between tillage method and tillage depth effects on soil crumbling was not significant at this aggregate size range.

Table 1 shows the complete results of analysis of variance for aggregate diameters. According to the Table 1, treatment (tillage method) and tillage depth had a significant effect on soil crumbling except on 2-mmdiameter aggregate size. Their interaction significantly affected the amount of soil crumbling as well.

\begin{tabular}{|c|c|c|c|c|c|c|c|c|c|c|c|c|}
\hline \multirow[b]{2}{*}{ Source of variation } & \multirow[b]{2}{*}{ df } & \multicolumn{11}{|c|}{ Mean square of soil aggregates with different diameters (mm) } \\
\hline & & 19 & 11.2 & 4.75 & 2.8 & 2 & 1.4 & 1 & 0.5 & 0.25 & $\mathrm{~d}<0.25$ & dsc \\
\hline Column effect & 3 & $7.299^{\mathrm{ns}}$ & $2.297^{\mathrm{ns}}$ & $3.592^{\mathrm{ns}}$ & $1.133^{\mathrm{ns}}$ & $0.353^{\mathrm{ns}}$ & $0.323^{\mathrm{ns}}$ & $2.43^{*}$ & $4.255^{\mathrm{ns}}$ & $1.912^{\mathrm{ns}}$ & $1.439^{\mathrm{ns}}$ & $0.306^{\mathrm{ns}}$ \\
\hline Row effect (replication) & 3 & $0.438^{\mathrm{ns}}$ & $0.921^{\mathrm{ns}}$ & $0.348^{\text {ns }}$ & $2.093^{*}$ & $2.596^{\mathrm{ns}}$ & $2.915^{*}$ & $5.351 * *$ & $1.857^{\mathrm{ns}}$ & $4.842^{\mathrm{ns}}$ & $12.249^{\mathrm{ns}}$ & $0.019^{\mathrm{ns}}$ \\
\hline Treatment effect & 3 & $86.279 * *$ & $96.051 * *$ & $114.862 * *$ & $11.607 * *$ & $0.185^{\mathrm{ns}}$ & $4.758 * *$ & $18.108^{* *}$ & $48.638^{* *}$ & $98.777 * *$ & $108.907 * *$ & $6.53 * *$ \\
\hline Depth effect & 4 & $31.647 * *$ & $33.582 * *$ & $28.067 * *$ & $1.765 *$ & $0.796^{\mathrm{ns}}$ & $1.569^{*}$ & $6.092 * *$ & $17.551^{* *}$ & $28.279^{* *}$ & $25.955^{* *}$ & $2.059 * *$ \\
\hline $\begin{array}{l}\text { Treatment and depth } \\
\text { interaction }\end{array}$ & 12 & $7.838^{\mathrm{ns}}$ & $11.137 * *$ & $14.876^{* *}$ & $2.033 * *$ & $0.716^{\mathrm{ns}}$ & $1.207^{*}$ & $1.619^{\mathrm{ns}}$ & $7.986^{* *}$ & $12.557 * *$ & $16.197^{*} *$ & $0.641^{* *}$ \\
\hline Major error & 6 & 2.620 & 3.721 & 3.300 & 0.240 & 0.827 & 0.470 & 0.272 & 4.512 & 4.266 & 5.030 & 0.202 \\
\hline Minor error & 48 & 4.181 & 2.288 & 1.844 & 0.639 & 0.385 & 0.477 & 1.445 & 1.851 & 2.969 & 3.896 & 0.188 \\
\hline
\end{tabular}

Table 1: The results of variance analysis of the aggregate sizes

${ }^{\mathrm{ns}}$ : No significant; *: Significant at the probability level of 5\%; **: Significant at the probability level of $1 \%$ 


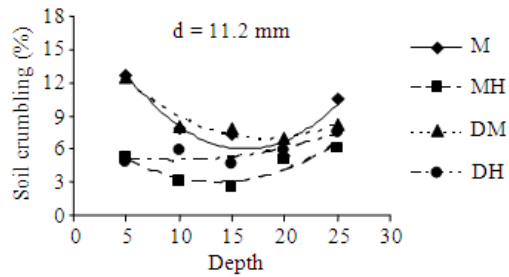

(a)

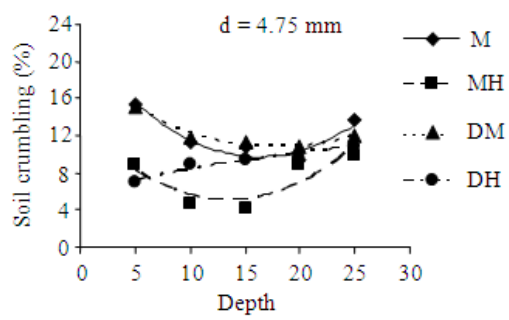

(b)

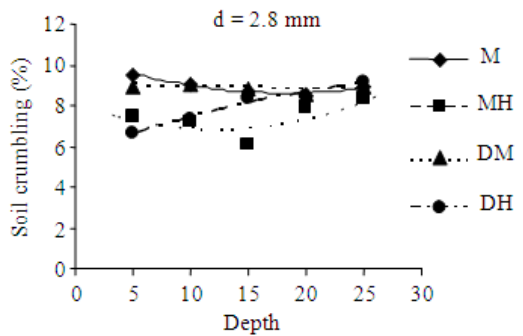

(c)

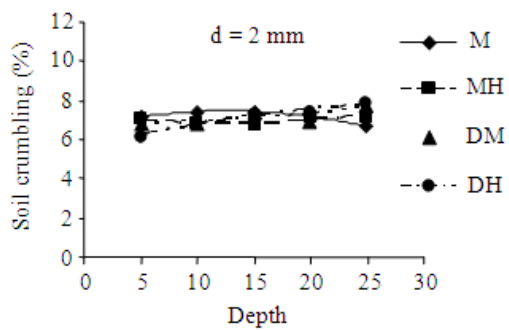

(d)

Fig. 1: Soil crumbling percentage versus sampling depth for 11.2, 4.75, 2.8 and $2 \mathrm{~mm}$ soil aggregate sizes

The diameter of soil aggregates produced by the moldboard plow and disc combination treatment was less than $2 \mathrm{~mm}$ which is favorable for crop growth ${ }^{[1]}$. This treatment also had the greatest percentage of soil crumbling ( $250 \mu \mathrm{m}$ and less).

Figure 1-3 show soil crumbling charts versus sampling depths (five levels) for the experimental treatments. The charts show that there is a non- linear correlation (polynomial) between soil crumbling and sampling depth with $R^{2} \geq 0.85$. Investigation of the charts could express soil crumbling or soil fragmentation at different soil depths in all treatments.

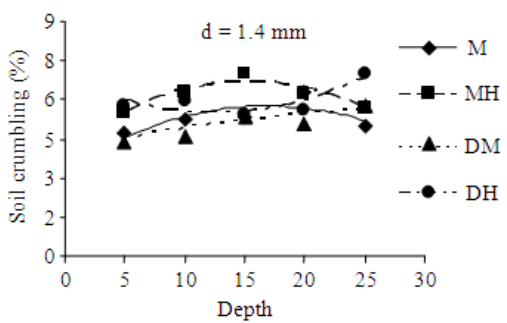

(a)

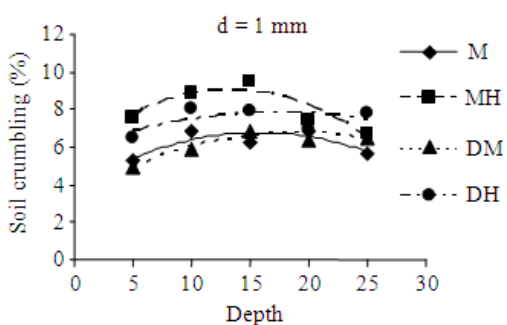

(b)

Fig. 2: Soil crumbling percentage versus sampling depths for 1.4 and $1 \mathrm{~mm}$ soil aggregate sizes

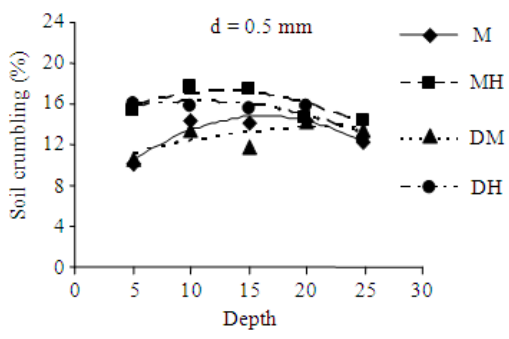

(a)

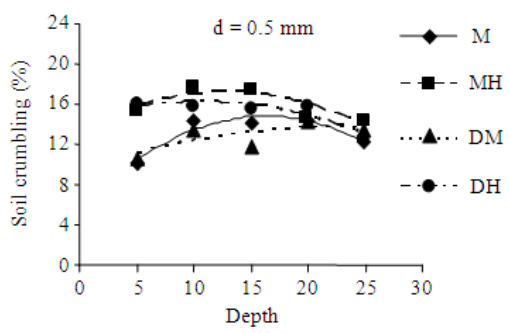

(b)

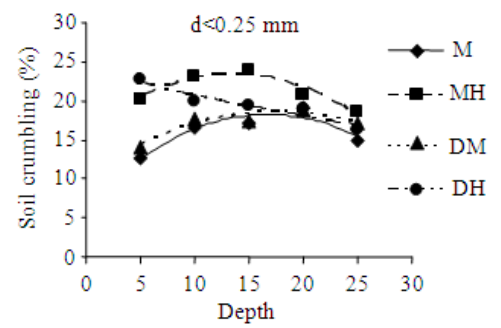

(c)

Fig. 3: Soil crumbling percentage versus tillage depths for $0.5,0.25 \mathrm{~mm}$ and less than $0.25 \mathrm{~mm}$ soil aggregate sizes 


\section{DISCUSSION}

The investigation of the charts of (a-d) in Fig. 1, showed soil crumbling trend with 2.8-19 mm particle size are the same for $\mathrm{MH}, \mathrm{M}$ and DM treatments. That is to say soil crumbling at shallow depth $(0-10 \mathrm{~cm})$ and deep depth $(20-25 \mathrm{~cm})$ are much more than intermediate depth $(15 \mathrm{~cm})$. While this trend is the same for DH treatment with $11.2-19 \mathrm{~mm}$ soil particle size, it has been reversed for $2.8-4.75 \mathrm{~mm}$ soil particles size. Statistical analysis of soil crumbling showed there are significant differences between treatments for four mentioned soil aggregate size categories in this study.

Figure 2a showed for soil particle size less than $2 \mathrm{~mm}$, soil crumbling trend are the same for $\mathrm{DH}$ and $\mathrm{M}$ treatments and also the same effect has been observed for $\mathrm{MH}$ and DM treatments. But there is not significant difference between treatments. Also soil crumbling rate at different soil depths is the same for all treatments.

In study of the soil crumbling for $1.4 \mathrm{~mm}$ soil aggregate size, reverse status occurred in comparison with soil particle size of $2.8 \mathrm{~mm}$. The charts for DM, $\mathrm{MH}$ and $\mathrm{M}$ treatments have maximum at soil depths of $15 \mathrm{~cm}$. While the soil crumbling chart for DH treatment have minimum at mentioned depth.

Investigation of soil crumbling for less than 0.25 , 0.25 and 0.5 soil aggregate sizes showed the same trend which has been shown in charts (a-c) in Fig. 3. That is to say in all treatments soil crumbling at $0-5,5-10,15-$ 20 and $20-25 \mathrm{~cm}$ soil depths is significantly less than soil depth of $10-15 \mathrm{~cm}$.

Also for soil aggregate sizes less than $250 \mu \mathrm{m}, \mathrm{DH}$ treatment showed different behavior in comparison with other treatments.

Mean diameters of aggregates at $10-20 \mathrm{~mm}$ depth matched each other and there was no significant difference between them. Finally, to gain particles with proper diameters $(0.25-2 \mathrm{~mm})$ for the sake of performing tillage operation in soils with loamy-clay texture, it is recommended to use the combination of Plow + Disc or De-Compactor + Disc and these are similar to the result of many studies such as ${ }^{[5,8,12,17]}$. So the $\mathrm{MH}$ treatment had the greatest amount of soil crumbling and the best seed-bed condition.

\section{CONCLUSION}

- Tillage methods and soil sampling depth have interaction effect on soil crumbling percentage

- The best soil conditions for seed-bed showed to be in $\mathrm{MH}$ and roughly in $\mathrm{DH}$ treatments

- There was non- linear correlation between soil crumbling and tillage depth with $\mathrm{R}^{2} \geq 0.85$
- The greatest percentage of soil crumbling $(250 \mu \mathrm{m}$ and less) was in moldboard plow followed by disk harrow)

\section{REFERENCES}

1. Akef, M. and I. Bagheri, 1999. Soil Management and the effects of agricultural machinery on soil physical properties. Guilan University Publication. ISBN: 964-6577-28-8, p. 305. (In Farsi).

2. Barzegar, A.R., J.M. Oades, P. Rengasamy and R.S. Murray, 1995. Tensile strength of dry, remoulded soils as affected by properties of the clay function. Geoderma, 65: 93-108. DOI: 10.1016/0016-7061(94)00028-9

3. Berntsen, R. and B. Berre, 1993. Fracturing of soil clods and the soil crumbling effectiveness of draught tillage implements. Soil Tillage Res., 28: 79-94. DOI: 10.1016/0167-1987(93)90057-V

4. Berntsen, R. and B. Berre, 2002. Soil fragmentation and the efficiency of tillage implements. Soil Tillage Res., 64: 137-147. DOI: 10.1016/S0167-1987(01)00251-3

5. Braunack, M.V. and A.R. Dexter, 1989. Soil aggregation in the seedbed: A review. II. Effect of aggregate sizes on plant growth. Soil Tillage Res., 14: 281-298. DOI: 10.1016/0167-1987(89)90014-7

6. Baybordi, M., 1993. Soil Physics. 5th Edn., University of Tehran Publications. No. 1672. ISBN: 964-03-4245-9, p. 672. (In Farsi)

7. Carter, M.R., 2004. Researching structural complexity in agricultural soils. Soil Tillage Res., 79: 1-6. DOI: 10.1016/j.still.2004.04.001

8. Gill, W.R. and W.F. McCreery, 1960. Relation of size of cut to tillage tool efficiency. Agric. Eng., 41: 372-374.

9. Gill, W.R. and G.E. Vanden Berg, 1967. Soil Dynamics in Tillage and Traction. USDA Agricultural Handbook no.316. U.S. Government Printing Office, ASIN: B000I8CH6E, p. 402

10. Karlen, D.L., D.C. Erbach, T.C. Kaspar, T.S. Colvin, E.C. Berry and D.R. Timmons, 1990. Soil tilth: A review of past perceptions and future needs. Soil Sci. Soc. Am. J., 54: 153-161. http://soil.scijournals.org/cgi/content/abstract/ 54/1/153

11. Kay, B.D. and A.R. Dexter, 1992. The influence of dispersible clay and wetting/drying cycles on the tensile strength of a red-brown earth. Aust. J. Soil Res., 30: 297-310. DOI: 10.1071/SR9920297

12. Ladd, J.N., R.C. Foster, P. Nannipieri and J.M. Oades, 1996. Soil Structure and Biological Activity. In: Soil Biochemistry, Strotzky, G. and J.M. Bollag (Eds.). Dekker, New York, USA., ISBN: 0824794419, pp: 568. 
13. Misra, R.K., A.R. Dexter and A.M. Alston, 1986. Maximum axial and radial growth pressures of plant roots. Plant Soil, 95: 315-326. DOI: 10.1007/BF02374612

14. Perfect, E. and R.L. Blevins, 1997. Fractal characterization of soil aggregation and fragmentation as influenced by tillage treatment. Soil Sci. Soc. Am. J., 61: 896-900. http://soil.scijournals.org/cgi/content/abstract /61/3/896

15. Perfect, E., M. Díaz-Zorit and J.H. Grove, 2002. A prefractal model for predicting soil fragment masssize distributions. Soil Tillage Res., 64: 79-90. DOI: 10.1016/S0167-1987(01)00246-X
16. Watts, C.W. and A.R. Dexter, 1997a. The influence of organic matter in reducing the destabilization of soil by simulated tillage. Soil Tillage Res., 42: 253-275. DOI: 10.1016/S01671987(97)00009-3

17. Watts, C.W. and A.R. Dexter, 1997b. Intensity of tillage of wet soil and the effects on soil structural condition. Proceedings 14th ISTRO Conference on Anonymous Fragmenta Agronomica TOM 2B, July 27- Aug. 1, Pulawy, Poland, pp: 669-672. 